\title{
ПРАВОВОЕ РЕГУЛИРОВАНИЕ ФРАНЧАЙЗИНГА В АВСТРАЛИИ
}

\author{
(C) 2019 Ющенко Наталья Анатольевна \\ кандидат юридических наук, доцент \\ Набережночелнинский институт Казанского федерального университета \\ 423800, РТ, г. Набережные Челны, пр-т Сююмбике, д. 10 \\ E-mail: yushchenko31@rambler.ru \\ (c) 2019 Гайфутдинова Розалия Закиевна \\ кандидат юридических наук, доцент \\ Набережночелнинский институт Казанского федерального университета \\ 423800, РТ, г. Набережные Челны, пр-т Сююмбике, д. 10 \\ E-mail: rozagayfutdinova@mail.ru \\ (c) 2019 Хасимова Лейсан Нафисовна \\ кандидат юридических наук, доцент \\ Набережночелнинский институт Казанского федерального университета \\ 423800, РТ, г. Набережные Челны, пр-т Сююмбике, д. 10 \\ E-mail: hasimov_l@mail.ru
}

В статье путем анализа законодательных актов, регулирующих франчайзинг, представлена система правового регулирования франчайзинговых отношений в Австралии, а также дана оценка их эффективности. Определены типы правового регулирования франчайзинговых отношений в мировой практике. Исследована деятельность Австралийской комиссии по конкуренции и защите прав потребителей (ACCC) по выявлению и пресечению нарушений во франчайзинговой деятельности.

Ключевые слова: франчайзинг, коммерческая концессия, интеллектуальная собственность, законодательство Австралии, Австралийская комиссия по конкуренции и защите прав потребителей, международное частное право.

Более двадцати лет назад в российском гражданском законодательстве был закреплен институт «коммерческой концессия», который является близким по своей правовой природе институту «франчайзинга» в мировой практике. Проводимые правовые реформы в нашей стране не смогли устранить противоречия в понимании этого института зарубежному опыту.

В российской доктрине посвящено достаточно много статей анализу проблем правового регулирования коммерческой концессии и его законодательному закреплению. Однако развитие мирового рынка, предполагает рассмотрение новых законодательных и правоприменительных практик в этой области.

На сегодняшний день сложилось три типа построения системы правового регулирования франчайзинговых отношений. Первый тип предусматривает принятие специальных законов о франчайзинге, регулирующие экономические и договорные отношения или только договорные отношения. Второй тип регулирования, базируется на включение договорных норм о франчай- зинге в гражданский кодекс. Третий тип основан на регулирование франчайзинговых отношений общими положениями о договорах и сделках, а также нормами иных отраслей права, в зависимости от вида отношений. На сегодняшний день законы о франчайзинге приняты в 36 странах мира, включая Австралию.

Франчайзинг основан на концепции, в рамках которой, франчайзер лицензирует свои права на результаты интеллектуальной собственности, включая ноу-хау и передает их на возмездной основе франчайзи по договору франшизы.

Франчайзинговые обязательства в основном строятся на договоре франшизы. Франшиза происходит от англо-французского слова «franc»«свободный» и используется как существительное и как глагол [1].

В Австралии франчайзинг регулируется Franchising Code of Conduct [2] (далее - Кодекс поведения по франчайзингу), и Competition and Consumer Act 2010 г. [3] (далее - Закон о конкуренции и защите прав потребителей), извест- 
ный ранее как Закон о торговой практике 1974 года.

Помимо Кодекса поведения по франчайзингу, стороны договора франшизы могут иметь обязательства, основанные на иных законодательных актах Австралии: 1) Fair Work Act, 2009 г. [4] (Закон о справедливой торговле); 2) Australian Securities and Investments Commission Act, 2001 г. [5] (Австралийский закон о ценных бумагах и инвестиций); 3) Income Tax Assessment Act, 1997 г. [6] (Закон об оценке подоходного налога).

Кодекс поведения по франчайзингу вступил в силу с 1 января 2015 года и применяется к франчайзинговым отношениям, возникшим после даты введения этого Кодекса. Однако соглашение о франшизе, заключенное до 1 января 2015 года, будет охватываться всем Кодексом поведения по франчайзингу, если соглашение будет продлено, передано или изменено каким-либо образом с 1 января 2015 года или после этой даты.

Указанный законодательный акт предусматривает, добросовестность сторон в обязательственных отношениях, штрафные санкции, раскрытие информации потенциальным франчайзи, ограничения по затратам и др. В частности, договор о франчайзинге не должен содержать условие, требующее от франчайзи оплаты франчайзеру расходов, понесенных франчайзером в связи с урегулированием спора в рамках соглашения.

Согласно п.5 Раздела 2 Кодекса поведения по франчайзингу, под договором франшизы понимается:

1) письменную или устную форму соглашения, а также соглашение, в котором лицо (франчайзер) предоставляет другому лицу (франчайзи) право заниматься предлагаемым бизнесом, поставки или распространения товаров или услуг в Австралии в рамках системы или маркетингового плана, в значительной степени определяемых, контролируемых или предлагаемых франчайзером или партнером франчайзера; а в соответствии, с которым деятельность предприятия будет по существу или материально связана с торговой маркой, рекламой или коммерческим символом (принадлежит, используется или лицензирован франчайзером или ассоциированным лицом франчайзера; или же указано франчайзером или ассоциированным лицом франчайзера); а также в соответствии с которым, перед началом или продолжением бизнеса франчайзи должен заплатить или согласиться выплатить франчайзеру или ассоциированному лицу франчайзера денежную сумму. Выплачиваемые франчайзи суммы могут включать: а) первоначальный взнос за капитальные вложения; б) оплату товаров или услуг; в) комиссионное вознаграждение, основанные на процентах от валового или чистого дохода, независимо от того, называются ли они гонораром за роялти или франшизу; г) плату за обучение.

При этом в вознаграждение не включаются: оплата товаров и услуг, поставляемых на основе оптовой торговли; погашение франчайзи ссуды от франчайзера или ассоциированного лица франчайзера; оплата за товары, взятые на консигнацию и поставленные на оптовой основе; выплата рыночной стоимости за покупку или аренду недвижимости, оборудования, оборудования или материалов, необходимых для начала бизнеса или продолжения бизнеса по договору франшизы.

Далее в Кодексе поведения по франчайзингу указывается, что считается договором франшизы: а) передача или продление договора франшизы; б) продление срока или объема франчайзингового соглашения; в) соглашение о продаже автомобилей.

Однако не является соглашением о франшизе: а) отношения работодателя и работника; б) партнерские отношения; в) отношения между арендодателем и арендатором; г) отношения залогодателя и залогодержателя; д) отношения кредитора и заемщика; е) отношения между членами кооператива, который зарегистрирован или образован в соответствии с законами о кооперации и кооперативах.

В понятии договора франшизы, используется термин, ассоциированный для франчайзера лицо. Согласно Кодексу поведения по франчайзингу ассоциированный для франчайзера лицо это лицо, которое, во-первых, является директором или юридическим лицом связанного органа или директором корпоративного юридического лица франчайзера; или же для франчайзера, который является частной компанией - прямо или косвенно владеет, контролирует или имеет право голоса, по крайней мере, 15\% выпущенных голосующих акций франчайзера; или же является партнером франчайзера; а также, чьи отношения с франчайзером имеют отношение к франчайзинговой системе, в том числе потому, что: а) лицо поставляет товары или услуги фран- 
чайзи; б) лицо дает франчайзи право занимать помещения, будь то в аренде или иным образом; в) лицо владеет интеллектуальной собственностью, используемой в системе франшизы; г) данное лицо вовлечено в исследование рынка, тестирование рынка, развитие рынка, стимулирование сбыта или управление системой франшизы.

Интересным представляется, предусмотренное Кодексом поведения по франчайзингу обязательство действовать добросовестно в соответствии с соглашением сторон и законом (п.6). При этом суд, рассматривая подобные споры, будет исходить из того, действовала ли сторона честно и содействовала ли она другой стороне для достижения целей соглашения. Эта норма в Кодексе поведения по франчайзингу является императивной и не может быть исключена или ограничена сторонами в соглашении. Действие же стороны в своих законных коммерческих интересах, рассматривается как добросовестное поведение.

Кодекс поведения по франчайзингу предусматривает основания расторжения договора франшизы в связи с: 1) «охлаждением»; 2) нарушением условий договора франчайзи; 3) условиями договора; 4) истечением срока действия договора; 5) особыми обстоятельствами.

Из перечисленных оснований, обращает внимание период «охлаждения» и особые обстоятельства.

Пункт 26 Кодекса поведения по франчайзингу, предусматривает расторжение договора франшизы периодом «охлаждения». Термин «охлаждение» законом не трактуется, но из смысла раскрываемой нормы видно, что франчайзи может расторгнуть договор франшизы, либо договор о заключении договора франшизы в течение 7 дней, даже если был осуществлен платеж в соответствии с этим соглашением. Если франчайзи прекращает действие соглашения, то франчайзер должен в течение 14 дней вернуть все платежи, сделанные франчайзи франчайзеру в соответствии с соглашением. Однако франчайзер может вычесть из возмещаемой суммы, разумные расходы франчайзера, если расходы или их метод расчета были предусмотрены в соглашении.

Согласно п.29 Кодекса поведения по франчайзингу особые обстоятельства применяются только к франчайзи, под которыми признаются: а) прекращение у франчайзи лицензии, не- обходимой для осуществления предпринимательской деятельности в рамках франчайзинга; б) банкротство франчайзи; в) снятие с учета Австралийской комиссией по ценным бумагам и инвестициям; г) добровольный отказ от занятия предпринимательской деятельности или франшизных отношений; д) осуждение франчайзи за тяжкое преступление; е) осуществление предпринимательской деятельностью, таким образом, при которой ставит под угрозу здоровье или безопасность населения; ж) франчайзи действует обманным путем при осуществлении предпринимательской деятельности, связанного с франчайзингом.

При возникновении спора по договору франшизы, закон предусматривает процедуру его урегулирования.

Заявитель направляет нарушителю письменное уведомление о характере спора, условиях восстановления нарушенного права и сроках их разрешения. Если стороны договора не могут разрешить конфликт в течение трех недель, то дело передается, назначенному сторонами посреднику (медиатору) в соответствии с условиями договора или на основании закона.

Медиатор назначает место и время для разрешения спора. Медиация осуществляется в Австралии. Присутствие сторон является обязательным, под угрозой штрафных санкций. Каждая из сторон спора вправе принимать участие в процедуре медиации через представителя.

Медиация прекращается по истечении 30 дней или если спор не был разрешен. Медиатор может прекратить процедуру в любое время, если не считает, что разрешение спора является неизбежным. Медиация может быть прекращена по заявлению одной из сторон.

При прекращении медиации, медиатор выдает сертификат сторонам и посредническому совету, в котором указывается наименование сторон, характер спора, окончание медиации и неурегулированность спора.

Расходы за урегулирование спора в рамках медиации, возлагаются на стороны равным образом, которые включают в себя: стоимость услуг медиатора, арендную плату, иные суммы, согласованные сторонами в качестве необходимых для проведения медиации (например, заключение экспертов).

Обобщая вышесказанное, можно сделать сказать, что Кодекс поведения по франчайзингу включает в себя три основных раздела: 1) рас- 
крытие соответствующей информации о франчайзере; 2) условия, содержащиеся в договоре о франшизе, и 3) процедуры рассмотрения жалоб и разрешения споров.

Australian Competition and Consumer Commission (далее - ACСС) - это Австралийская комиссия по конкуренции и защите прав потребителей, которая является независимым органом правительства Австралии. Основной ее задачей является защита прав потребителей, прав и обязанностей предпринимателей, регулирование отраслей экономики, мониторинг цен, а также предотвращение незаконного антиконкурентного поведения. АССС также предоставляет информацию предпринимателям, заключающим, продляющим или возобновляющим договор франшизы.

ACСС обеспечивает соблюдение Закона о конкуренции и защите прав потребителей и Кодекса поведения по франчайзингу, который вправе возбуждать дела в Федеральном суде Австралии по защите конкуренции и прав потребителей. За нарушение законодательства о конкуренции и защите прав потребителей предусмотрена административная ответственность в виде штрафа. Некоторые составы правонарушений могут быть квалифицированы как уголовные преступления и предусматривать ответственность до десяти лет лишения свободы. Например, составами преступления являются заключение договора, содержащего положение о картеле (ст. 44ZZRF), а также приведение в действие положение о картеле (ст. 44ZZRG)

ACCС имеет право обеспечивать от своего имени судебные решения в соответствии со ст. 87В Закона о конкуренции и защите прав потребителей, которые включают в себя широкий спектр средств защиты от неправомерного поведения.

При выявлении нарушения, АССС выдает одно или несколько уведомлений о нарушении законодательства с указанием штрафных санкций, в течении двенадцать месяцев с момента выявления нарушения. Лицо, получившее такое уведомление не имеет никаких юридических обязательств по оплате штрафа. Однако в дальнейшем ACCC вправе обратиться в суд с требованием о привлечении виновного, по его мнению, к ответственности. В некоторых случаях, уведомление о нарушении может быть обеспечено дополнительными средствами правовой защиты, в том числе посредством судебных решений. Например, если требуется опровержение, достоверная реклама или возмещение ущерба потребителю. АССС без выдачи уведомления о нарушении вправе сразу обратиться в суд, если нарушения носят существенный характер, причинен значительный ущерб, длительность нарушения, неоднократность нарушения и в других случаях.

При выдаче уведомления о нарушении АССС предоставляет информацию о характере нарушения, сумме штрафа, периоде его платежа и правовые последствия неисполнения уведомления. Период оплаты штрафа составляет 28 дней и может быть продлен еще на такой же срок. Продлевая срок оплаты штрафа, получатель уведомления обязан сообщить АССС намерен ли он оплатить штраф, обстоятельства, препятствующие оплате штрафа в срок и причины выполнения обязательства в новый срок. Следует учитывать, что оплата штрафа не лишает права иных лиц на обращения в суд за защитой своих права. АССС, в соответствии с принципом прозрачности своей деятельности, ведет реестр на своём официальном сайте оплаченных уведомлений о нарушениях. Получатель уведомления вправе требовать отзыва уведомления о нарушении, в случае если он не является субъектом правонарушении.

В случае судебного разбирательства нарушения законодательства Австралии, судом может быть наложен штраф значительно выше, чем в уведомлении, выданного АССС [7].

Наделение АCCС полномочием выдачи уведомления о нарушении является одним из инструментов правоприменения и позволяет своевременно и эффективно разрешать споры без судебного разбирательства.

\section{Библиографический список}

1. Harper D. Online Etymology Dictionary. 2001-2019.//www.etymonline.com/word/franchise.

2. Franchising Code of Conduct, 30.10.2014, Act № 168. Federal Register of Legislation - Australian Government. // www.legislation.gov.au/Details/F2014L01472.

3. Competition and Consumer Act 2010. Act № 2. (Includes amendments up to: 31.10.2017, Act № 116). Federal Register of Legislation - Australian Government. // www.legislation.gov.au/Series/C2004A00109. 
4. Fair Work Act, 2009, 07.04.2009, Act № 28. (Includes amendments up to: 12.12.2018, Act № 170). Federal Register of Legislation - Australian Government. // HYPERLINK «http://www.legislation.gov.au/Details/C2018C00512».

5. Australian Securities and Investments Commission Act, 28.06.2001, Act № 51. (Includes amendments up to: 26.10.2018, Act № 132). Federal Register of Legislation - Australian Government. // HYPERLINK «http://www. legislation.gov.au/Details/C2018C00438».

6. Income Tax Assessment Act, 17.04.1997, Act № 38. (Includes amendments up to: 12.10.2017, Act № 108). Federal Register of Legislation - Australian Government. // HYPERLINK «https://www.legislation.gov.au/Details/ C2017C00336».

7. Compliance and Enforcement Policy and Priorities. ACCC. 26.02.2019. // https://www.accc.gov.au/publications/ compliance-and-enforcement-policy. 